\title{
PENELITIAN KONSEPTUAL: PENINGKATAN KUALITAS STRATEGIS MELALUI PENGGUNAAN TEKNOLOGI INFORMASI DAN KOMUNIKASI DALAM MENINGKATKAN KINERJA PEMERINTAH DAERAH
}

\author{
Zulkifli $^{1}$, Tatiek Nurhayatie ${ }^{2}$, Muhammad Junaidi ${ }^{3}$ \\ ${ }^{1}$ Mahasiswa Program Doktor Ilmu Manajemen, Fakultas Ekonomi Universitas Islam Sultan \\ Agung; ${ }^{2}$ Fakultas Ekonomi Universitas Islam Sultan Agung; ${ }^{3}$ Fakultas Hukum Universitas \\ Semarang \\ 12zulkifli737@yahoo.com; ${ }^{2}$ tatiek@unissula.ac.id; 3institut.junaidi@ gmail.com
}

\begin{abstract}
The quality of planning and synchronization in implementation can be seen from the large number of community participation in the development process. So that public participation in the 4.0 industrial revolution can be realized through the use of technology. The concept offered by this research is the role of Strategic Quality in improving the performance of local government, which places ICT as a moderating variable.
\end{abstract}

\section{Keywords: Planning Quality, Implementation Quality, ICT}

Abstraksi. Kualitas perencanaan dan sinkronisasi dalam implementasi dapat dilihat dari banyaknya partisipasi masyarakat dalam proses pembangunan. Sehingga peran serta masyarakat dalam revolusi industri 4.0 ini dapat diwujudkan melalui pemanfaatan teknologi. Konsep yang ditawarkan oleh penelitian ini adalah peran Kualitas Strategis dalam meningkatkan kinerja pemerintahan daerah, yang menempatkan Teknologi Informasi dan Komunikasi (TIK) sebagai variabel moderasinya.

\section{Kata kunci: Kualitas Perencanaan, Kualitas Implementasi, TIK}

\section{PENDAHULUAN}

Pandangan yang berkembang dalam abad 21 salah satunya perubahan cara hidup ke arah yang lebih fleksibel, yang sering kita kenal sebagai Revolusi Industri 4.0. Konsep revolusi industri 4.0 pada hakikatnya dikembangkan oleh ilmuan barat, pertama kali dikembangkan oleh Klaus Schwab seorang ahli manajemen dalam bukunya yang berjudul "The Fourth Industrial Revolution". Schwab (2017) menjelaskan bahwa dalam era revolusi industri ke 4.0 akan mampu mengubah pola hidup, pola pikir dan cara kerja manusia. Perubahan cara kerja manusia salah satu dalam revolusi industri ini adalah penggunaan teknologi informasi, dimana jarak kerja dan batasan wilayah bukan lagi menjadi tantangan, karena dalam era ini semua bisa tersambung dengan memanfaatkan teknologi. Hal tersebut menjadi salah satu ciri karakteristik dari revolusi Industri 4.0.

Pemanfaatan teknologi dalam meningkatkan kinerja organisasi pemerintahan menjadi salah satu pembahasan yang menari, dalam pengembangan manajemen strategis. Pemanfaatan teknologi dalam meningkatkan kualitas perencanaan dan transparansi penyelenggaraan pemerintah daerah, pada hakikatnya sudah diamanatkan dalam Undang - Undang Nomor 14 Tahun 2008 tentang keterbukaan informasi publik. Salah satu kewajiban pemerintah daerah adalah membuka transparansi penyelenggaraan pemerintahan daerah. Transparansi penyelenggaraan pemerintahan daerah 
merupakan salah satu cara untuk meningkatkan kinerja pemerintah daerah.

Penggunaan teknologi pada hakikatnya bisa dijadikan sebagai sarana untuk meningkatkan kualitas strategis dalam organisasi pemerintahan daerah. Menon, Bharadwaj et al. (1996) menjelaskan kualitas strategi adalah strategi yang dikembangkan menjadi power yang kuat dalam organisasi terdiri dari kualitas perencanaan strategi, kualitas implementasi strategi dan kualitas evaluasi strategi. Pemanfaatan teknologi dalam meningkatkan kualitas strategis dengan tujuan akhir memaksimalkan kinerja dari hasil penelitian Sudarsana (2018) dengan adanya pemanfaatan teknologi dalam kualitas strategi mendapatkan umpan balik dari publik positif dari publik. Namun hasil penelitian (Hadi, Handajani et al. 2018) keterbukaan informasi publik melalui teknologi tidak selamanya berdampak positif terhadap kinerja, hasil studinya menunjukkan bahwa umpan balik negatif dari publik berdampak negatif terhadap kinerja.

Sedangkan harapan dari umpan balik publik terhadap kualitas strategis, organisasi pemerintahan daerah diharapkan akan mampu meningkatkan kinerja organisasi pemerintahan daerah. Karena peran kualitas strategi dalam organisasi pemerintahan daerah sangat vital. Larcker (1997) menerangkan bahwa organisasi menempatkan kualitas strategi menjadi unsur pokok dalam meningkatkan kinerja, yang ditekankan pada kualitas strategi perencanaan, implementasi organisasi. Berdasarkan penjelasan tersebut penelitian ini akan mengisi celat gap yang terjadi, dengan harapan bahwa pemanfaatan teknologi dalam pengelolaan pemerintah daerah, mampu meningkatkan kinerja organisasi pemerintahan daerah.

\section{METODOLOGI}

Kajian literatur yang secara komprehensip dibahas dapat menciptakan sebuah model penelitian yang dapat dikembangkan dalam penelitian empirik selanjutnya. Berdasarkan penjelasan dan kajian secara komprehensip tersebut, model yang dikembangkan dalam penelitian ini sebagi berikut :

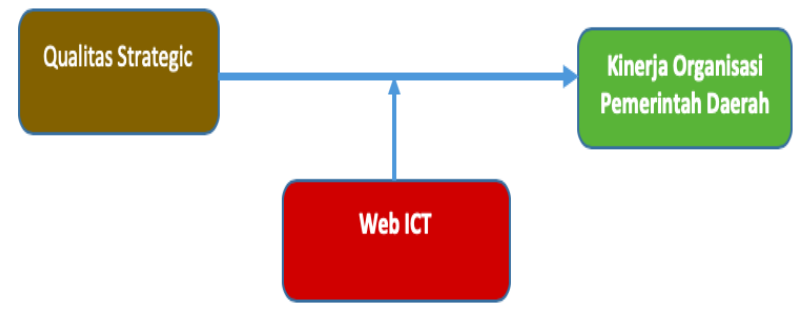

Gambar 1. Model Penelitian Konseptual

\section{PEMBAHASAN}

\section{Kualitas Strategis, TIK dan Kinerja Organisasi Pemerintahan}

Strategi merupakan keseluruhan dari rencana yang bersifat kompetitif dalam suatu organisasi, yang berhubungan dengan pengambilan keputusan organisasi dalam menghadapi masalah lingkungan internal dan eksternal dalam mencapai tujuan (Hambrick 1980). Ditambahkan oleh Widodo (2011) kualitas strategis merupakan tingkat kelengkapan dan keterpaduan antara proses perencanaan strategi dengan kejelasan dalam implementasi strategi dan proses evaluasi strategi. Masalah yang mendasar dalam manajemen strategi adalah bagaimana organisasi mampu meningkatkan kinerja secara maksimal 
dan mempertahankan keunggulan bersaing (Teece, Pisano et al. 1997). Hasil studi Manning and Larcker (1997) menerangkan bahwa organisasi menempatkan kualitas strategi menjadi unsur pokok dalam meningkatkan kinerja, yang ditekankan pada kualitas strategi perencanaan organisasi. Persoalan utama dari tidak berdampaknya penurunan kemiskinan dalam organisasi pemerintahan adalah, banyaknya implementasi kegiatan yang tidak selaras dengan perencanaan (Zulkifli, Susanti et al. 2019)

\section{Kualitas Strategi Perencanaan}

Perencanaan menjadi sebuah isu yang menarik dalam penelitian, karena strategi perencanaan merupakan awal dari sebuah implementasi kerja. Menurut Wolf and Floyd (2013) berpendapat bahwa strategi perencanaan harus menganut prinsip praktis, partisipatif dan mudah diaplikasikan. Hal tersebut menjadi sebuah prinsip mendasar dalam sebuah perencanaan, prinsip-prinsip mendasar tersebut akan mampu meningkatkan kualitas strategi perencanaan yang hakikatnya, sangat ditentukan oleh partisipasi stakeholder dalam proses penyusunannya. Hasil penelitian Napitupulu, Hakim et al. (2016) prinsip partisipasi dan transparansi sangat menentukan kualitas perencanaan. Menurut (Johnsen 2018) kualitas perencanaan merupakan proses pembentukan perencanaan yang melibatkan pengambil keputusan dan stakeholder. Ditambahkan oleh Said, Andrews et al. (2016) strategi perencanaan merupakan serangakaian penyusunan kegiatan yang mengikuti prosedur organisasi, untuk menciptakan perencanaan yang strategis. Berdasarkan penjelasan diatas kualitas strategi perencanaan adalah: proses penyusunan perencanaan yang berorientasi peningkatan kinerja yang melibatkan banyak stakeholder dengan prinsip transparan, praktis, partisipatif dan mudah di aplikasikan

Studi Napitupulu, Hakim et al. (2016) menjelaskan kualitas perencanaan dapat dilihat dari proses, yang terdiri dari tahap persiapan, tahap pengumpulan data, tahap pengolahan dan analisis data, tahap penyusunan konsep dan tahap penyusunan dokumen perencanaan, selanjutnya prosedur penyusunan dapat dilihat dari pembentukan tim penyusunan, pelaksanaan penyusunan, pelibatan peran masyarakat, konten pembahasan. Ditambahkan oleh Widodo (2011) kualitas strategi dalam perencanaan dapat dilihat dari adabtasi, konten, kelengkapan, integrasi, mengembangkan pengetahuan, meningkatkan komitmen dan meningkatkan kualitas komunikasi. Kualitas perencanaan dalam pemerintahan menurut Johnsen (2018) dapat dilihat dari konten dokumen perencanaan, stakeholder yang terlibat dalam penyusunan perencanaan, alat yang digunakan dalam proses perencanaan, tindakan strategis yang dilakukan dalam proses perencanaan dan sikap dalam menyusun perencanaan. Berdasarkan penjelasan di atas indikator yang digunakan dalam studi ini adalah : proses penyusunan perencanaan, konten dari dokumen perencanaan, kelengkapan dari dokumen perencanaan, partisipatif dalam penyusunan perencanaan. 
Kinerja organisasi dalam sektor publik sangat sulit menentukannya, dimana semua kepentingan memiliki sudut pandang tertentu dalam menentukan kinerja organisasi dalam sektor publik. Karateristik daerah dan kepentingan politik sangat menentukan indikator atas kinerja yang ingin dicapai (Hadi, Handajani et al. 2018). Ditambahkan oleh Adhi and Fachrunnisa (2017) kinerja organisasi merupakan tolak ukur dari kemampuan organisasi dalam mencapai keberhasilan organisasi yang telah ditentukan. Ditambahkan oleh Priansa (2018) kinerja organisasi merupakan tampilan keadaan organisasi secara utuh, selama periode waktu tertentu, yang didalamnya terdapat hasil atau prestasi yang dipengaruhi oleh kegiatan organisasi dalam memanfaatkan sumber daya yang dimiliki. Berdasarkan beberapa uraian tersebut dapat simpulkan bahwa kinerja organisasi pemerintahan adalah : tampilan keadaan organisasi secara utuh dalam mencapai tujuan yang di dasarkan pada karakteristik daerah dan kepentingan politik. Berdasarkan penjelasan tersebut dapat dirumuskan proposisi yang dikembangkan dalam penelitian ini adalah.

P1.: semakin baik Kualitas Strategis Perencanaan pembangunan pemerintah daerah maka semakin baik kinerja organisasi pemerintah daerah

\section{Kualitas Strategi Implementasi}

Menurut Said, Andrews et al. (2016) kualitas implementasi merupakan penilaian atas pelaksanaan kegiatan berdasarkan kualitas perencanaan yang sudah di tetapkan organisasi. Siapei
(2015) menjelaskan bahwa kualitas implementasi merupakan pelaksanaan kegiatan organisasi yang mengedepankan efisiensi, ketepatan waktu untuk mencapai kinerja yang baik.

Penelitian Wibowo, Hakim et al. (2015) indikator implementasi adalah pengalaman implementator, fasilitas pendukung implementasi, tingkat pemahaman implementator setelah pelatihan, frekuensi pertemuan, saranan menginformasikan implementasi, metode menginformasikan, minat implementator, koordinasi antar implementator, perubahan aturan, keterlibatan implementator dalam perencanaan, keterlibatan implementator dalam evaluasi. Ditambahkan oleh Widodo (2011) kualitas strategi dalam implementasi terdiri dari koordinasi, pola kerja cerdas, orientasi pembelajaran, kolaborasi, komitmen kerja dan komunikasi informal. Selanjutnya menurut Said, Andrews et al. (2016) kualitas implementasi dapat dilihat dari sejauh mana pelaksanaan mengikuti dokumen perencanaan, seberapa baik pelaksanaan yang kerjakan, seberapa penting tugas implementasi terhadap capaian perencanaan, kepuasan terhadap pelaksanaan. Ditambahkan oleh Siapei (2015) indikator kualitas strategi implementasi adalah ketepatan waktu dalam bekerja, pelaksanaan yang berkelanjutan, efisiensi anggaran, kreativitas dalam pelaksanaan. Berdasarkan uraian tersebut dapat dirumuskan indikator kualitas strategi implementasi adalah: Pemahaman Implementator, kesesuaian pelaksanaan dengan perencanaan, orientasi 
pembelajaran, efisiensi anggaran dan ketepatan waktu dalam pelaksanaan.

Kinerja organisasi sektor publik hasil Penelitian Muterera, Hemsworth et al. (2018) indikator kinerja terdiri dari tujuan yang rasional, keterbukaan sistem, proses internal dan hubungan manusia. Studi yang dilakukan oleh Suprianto (2014) kinerja pemerintahan dapat diukur dari jumlah sumber daya manusia yang terlibat, pertumbuhan kelompok masyarakat, peningkatan kegiatan ekonomi dan penurunan tingkat kemiskinan. Indikator kinerja organisasi menurut Adhi and Fachrunnisa (2017) terdiri dari kualitas sumber daya manusia, kepuasan sumber daya manusia dan pertumbuhan organisasi. Selanjutnya dalam penelitian Hadi, Handajani et al. (2018) menjelaskan indikator kinerja keuangan dalam sektor publik dapat dilihat dari rasio ketergantungan pemerintah daerah dan rasio belanja daerah.

Menurut Priansa (2018) kinerja organisasi pemerintahan dapat dilihat dari efektivitas operasional, efektivitas struktur, implementasi sasaran organisasi, menjalankan standar operasional organisasi dan mengikuti peraturan yang berlaku. Berdasarkan uraian tersebut dapat disimpulkan indikator kinerja organisasi pemerintahan yang digunakan dalam studi ini adalah: pertumbuhan organisasi, ketergantungan organisasi, kualitas sumber daya manusia, peningkatan kegiatan ekonomi dan rasio belanja daerah. Berdasarkan hal tersebut proposisi yang dikembangkan dalam penelitian ini adalah :

P2.: semakin bersinergi antara Kualitas Strategis Perencanaan dengan implementasi pembangunan pemerintah daerah maka semakin baik kinerja organisasi pemerintah daerah

Pemanfaatan teknologi sebagai sarana menuju transparansi, penyelenggaraan Pemerintah Daerah sudah menjadi suatu topik penelitian yang menarik untuk dikaji. Menurut Putra, Jasmi et al. (2018) Teknologi Informasi dan Komunikasi merupakan suatu teknologi yang paling tepat dan cepat berkembang, terutama dalam penyelenggaraan pemerintahan. Perkembangan TIK akan membuka peluang dan tantangan untuk menciptakan, mengakses, memproses dan memanfaatkan informasi akurat dalam organisasi. Dalam era revolusi industri 4.0 sudah saatnya pemerintah daerah menerapkan pengembangan teknologi informasi, karena pada hakikatnya teknologi informasi mampu meningkatkan efisiensi, kecepatan dalam pengiriman informasi, jangkauan global dan transparansi (Putra, Handajani et al. 2018). Namun perkembangan teknologi untuk menciptakan efisiensi, tidak berbanding lurus jika diterapkan dalam organisasi pemerintahan daerah hal tersebut terbukti dari hasil penelitian Hadi, Handajani et al. (2018) dan Putra, Jasmi et al. (2018) menyatakan bahwa penerapan teknologi dalam pengelolaan organisasi pemerintahan tidak mampu meningkatkan kinerja. Ditambahkan oleh Nam (2018) bagi daerah atau negara yang sudah berkembang penerapan teknologi akan berdampak positif terhadap kinerja pemerintahan. Berdasarkan penjelasan tersebut TIK merupakan teknologi untuk meningkatkan transparansi untuk 
melibatkan sumber daya manusia dalam pengambilan keputusan

Penerapan teknologi informasi dalam penyelenggaraan pemerintah daerah akan mampu meningkatkan partisipasi publik dalam meningkatkan kualitas strategi. Salah satu ciri dari perencanaan dan implementasi yang berkualitas adalah banyaknya peran serta publik dalam penyelenggaraan pemerintahan. Hal tersebut selaras dengan hasil penelitian Michener, Worthy et al. (2018) bahwa penerapan teknologi informasi akan meningkatkan partisipasi publik, sehingga dengan terciptanya transparansi, akan banyak melibatkan proses dan sumber daya manusia dalam menentukan kebijakan. Berdasarkan penjelasan tersebut proposisi yang dikembangkan dalam penelitian ini adalah :

P 3: kualitas strategis akan berdampak terhadap kinerja organisasi pemerintahan daerah, namun dengan adanya peran Web TIK, akan meningkatkan pengaruhnya, melalui transparansi dan keterlibatan sumber daya manusia yang berkualitas.

\section{SIMPULAN}

Kualitas strategi yang terdiri dari kualitas strategi perencanaan dan kualitas strategi implementasi, akan menajadi sebuah elemen penting dalam penyelenggaraan pemerintah daerah. Salah satu yang menjadi pokok penting adalah dalam perencaan adalah terukurnya indikator yang digambarkan dari konten yang terdapat dalam dokumen perencanaa. Sehingga akan bersinergi dengan implementasi yang akan dilaksanakan. Kualitas strategi pada prinsipnya dapat diwujudkan melalui pendekatan partisipasi, partisipasi yang diharapkan adalah peran publik dalam perencanaan dan implementasi, dimana publik dijadikan sebagai kontrol dalam penyelenggaraan pemerintahan. Sehingga tranfaransi melalui penerapan teknologi dapat menjadi salah satu model dalam meningkatkan kualitas strategi.

Perencaan dna implementasi yang berkualitas melalui pendekatan partisipatif akan mampu menjadi prisai dalam pembangunan daerah. Peran teknologi merupakan peran untuk memberikan singnaling kepada masyarakat untuk ikut berpartisipasi memberikan pengawasan da memberikan masukan kepada penyeneggaraan pemerintahan daerah. Selain dari peran partisipastif teknologi dapat menjadi sarana pembelajaran bagi daerah yang baru berkembang, untuk memberikan pembelajaran kepada masyarakat, untuk meningkatkan pasrtisipasi terhadap pembangunan daerahnya.

Konsep penelitian ini dapat diterapkan dalam penelitian yang akan datang secara empirik untuk organisasi pemerintahan di indonesia yang mayoritas pemerintah kabupaten/kota belum memanfaatkan teknologi dalam meningkatkan tranfaransi. Walaupun dalam regulasi sudah menjadi persoalan yang perlu diterapkan. Selain itu dalam pemerintahan daerah sangat identik, dengan kepentingan politik, sehingga transparansi sering tidak menjadi prioritas utama dalam meningkatkan kienrja. Sehingga diperlukan sebuah konsep yang di uji secara empirik dari model ini, serta lebih menonjolkan halhal yang baru yang memberikan 
kontribusi bagi pembangunan daerah serta perkembangan ilmu pengetahuan dan teknologi, diutamakan implikasinya dalam kehidupan sehingga hasil penelitian dapat memberi kemanfaat yang besar dan juga menyelesaikan permasalahan bangsa.

\section{DAFTAR PUSTAKA}

Adhi, S. M. and O. Fachrunnisa (2017). "Peran Perilaku Kerja Berbasis Praktek Manajemen Sumber Daya Manusia Islami Menuju Peningkatan Kinerja Organisasi." Jurnal Manajemen dan Bisnis Indonesia 5(1): 34-47.

Hadi, A., L. Handajani and I. N. N. A. Putra (2018). "Financial Disclosure based on WebICT Determinants: Its Implications for Local Government Financial Performance in Indonesia." International Research Journal of Management, IT and Social Sciences (IRJMIS) 5(1): 72-85.

Hambrick, D. C. (1980). "Operationalizing the Concept of Business-Level Strategy in Research." Academy ot Management Review 5(4): 567-575.

Johnsen, A. (2018). "Impacts of strategic planning and management in municipal government: an analysis of subjective survey and objective production and efficiency measures in Norway." Public Management Review 20(3): 397-420.

Larcker, C. D. I. m. n. A. D. F. (1997). "Quality Strategy, Strategic Control Systems, And Organizational Performance." Accounting,Organizations and .Society. 22(3/4): 293314.

Manning, C. D. and D. F. Larcker (1997). "Quality Strategy, Strategic Control Systems, And Organizational PerformancE." Accounting, Organizations and .Society. 22(3/4): 293-314.

Menon, A., S. G. Bharadwaj and R. Howell (1996). "The Quality and Effectiveness of Marketing Strategy: Effects of Functional and Dysfunctional Conflict in Intraorganizational Relationships " Journal of the Academy of Marketing Science. 24(4): 299-313.

Michener, G., B. J. A. Worthy and Society (2018). "The information-gathering matrix: A framework for conceptualizing the use of freedom of information laws." 50(4): 476500.

Muterera, J., D. Hemsworth, A. Baregheh and B. R. Garcia-Rivera (2018). "The leaderfollower dyad: The link between leader and follower perceptions of transformational leadership and its impact on job satisfaction and organizational performance." International Public Management Journal 21(1): 131-162.

Nam, T. J. G. I. Q. (2018). "Examining the anti-corruption effect of e-government and the moderating effect of national culture: A cross-country study." 35(2): 273-282.

Napitupulu, M. Y., A. Hakim and I. Noor (2016). "Penerapan Prinsip Good Governance Dan Pengaruhnya Terhadap Penyusunan Rencana Tata Ruang Wilayah (RTRW) Dalam Perencanaan Tata Ruang Daerah Studi pada Penyusunan RTRW Kabupaten Serdang Bedagai." WACANA, Jurnal Sosial dan Humaniora 19(4). 
Priansa, D. J. (2018). Manajemen Organisas Publik "Mengembangkan Organisasi Modern Berorientasi Publik". Bandung, Pustaka Setia.

Putra, D. A., K. A. Jasmi, B. Basiron, M. Huda, A. Maseleno, K. Shankar, N. J. I. J. o. P. Aminudin and A. Mathematics (2018). "Tactical Steps for E-Government Development." 119(15): 2251-2258.

Putra, I. N. N. A., L. Handajani and A. Hadi (2018). "Financial Disclosure based on WebICT Determinants." International Research Journal of Management, IT \& Social Sciences 5(1).

Said, E., Andrews, R. William and P. Raili (2016). "Strategic planning and implementation success in public service organizations: evidence from Canada." Public Management Review 18(7): 1017 -1042.

Schwab, K. (2017). The fourth industrial revolution, Crown Business.

Siapei, I. (2015). Organizational Structure and Strategy Implementation at Geothermal Development Company in Kenya, University of Nairobi MBA Project, Nairobi: Kenya.

Sudarsana, I. K. J. C. J. I. P. (2018). "Optimalisasi Penggunaan Teknologi Dalam Implementasi Kurikulum Di Sekolah (Persepektif Teori Konstruktivisme)." 1(1): 815.

Suprianto, E. (2014). "Pengaruh Penerapan Tata Kelola Pemerintahan Yang Baik Dan Teknologi Informasi Terhadap Kinerja Satuan Kerja Perangkat Daerah (SKPD) Guna Mendukung Implementasi Otonomi Daerah." Jurnal Ekonomi \& Bisnis 15(1): 17-30.

Teece, D. J., G. Pisano and A. Shuen (1997). "Dynamic Capabilities And Strategic Management." Strategic Management Journal, 18(7): 509-533

Wibowo, S., A. Hakim and M. Makmur (2015). "Implementasi Sistem Informasi Puskesmas Elektronik (SIMPUSTRONIK) dan Hubungan Dengan Pelayanan Kesehatan Ibu dan Anak (KIA)(Studi Perbandingan Implementasi di Puskesmas Sumberasih dan Puskesmas Paiton Kabupaten Probolinggo)." WACANA, Jurnal Sosial dan Humaniora 18(3).

Widodo, W. (2011). "Building Strategy Quality." International Journal of Business and Management 6(8).

Wolf, C. and S. W. Floyd (2013). "Strategic Planning Research: Toward a Theory Driven Agenda." Journal of Management $\mathbf{X X}(\mathrm{X}):, 1-35$.

Zulkifli, Susanti and W. R. Novia (2019). "Evaluation of the Aceh Provincial Government Performance on the Quality of Life of Acehnese: Through a Strategy Quality Approach." Academy of Strategic Management Journal 18(2): 1-9. 